\title{
Faulty Dietary Habits vis-à-vis Acne Vulgaris: An Epidemiological Study
}

\author{
Research Article
}

\section{Talekar Manisha $^{1^{*}}$, Mandal Sisir Kumar ${ }^{2}$, Deshmukh Prashant Nareshrao ${ }^{3}$, Vaish Gaurav ${ }^{1}$}

\author{
1. PG Scholar, 2. Assistant Professor, 3. Ph.D Scholar, \\ Roganidana evam vikriti vijanana department, National Institute of Ayurveda, Jaipur.
}

\begin{abstract}
Background: In day to day life, person consumes an incompatible diet and faulty food habits which leads to most of the diseases. Y uvanapidaka (Acne vulgaris) is one of the common skin disease which is affected by faulty dietary intake.

Aims and Objective: To conduct a survey study on faulty dietary habits in Acne vulgar is patients and to find out cause-effect relationship between them.

Materials and Methods: Total 210 patients having signs and symptoms of Acne vulgaris were selected from NIA O.P.D., I.P.D., various camps in Jaipur \& certain junk food outlets. Patients were screened on the basis of specially prepared questionnaires.

Results: On survey study, $100 \%$ patients were consuming Junk food \& dairy products \& incompatible diet. Maximum no. of patients was taking high glycemic index diets which play an important role in aggravation of acne.

Conclusion: Maximum prevalence of faulty dietary habits was found in patients. So it was concluded that dairy products, incompatible diets, high glycemic index diet, junk foods which is responsible for formation of acne vulgaris.
\end{abstract}

Keywords: Acne; junk food; incompatible diet; dairy products; high glycemic index

\section{Introduction:}

Beauty is the reflection of the personality of the individual. The first and foremost reflection of the person is face and any disfigurement or scars of the face have a high impact on social and individual personality. In the present day society each and everyone is beauty conscious. Acne, however, has a significant impact on a person's outlook on life. Ample references are available regarding beauty tips in ancient popular Ayurvedic Samhitas as well as in allied science. As mentioned in Ayurvedic Samhitas, Yuvanapidaka (acne vulgaris) is a pathological situation of the skin which is produced due to the vitiation of Kapha, Vata and Rakta. The disease predominantly afflicts the Raktavaha Srotasa, Doshas (body humors) getting localized in the skin producing cardinal features such as Todayukta (painful), Ghana (immobile), Shalmalikantakavata Pidaka (pimple). It's similar clinical presentation in modern dermatology can be traced as Acne vulgaris, which is a distressing condition which is related to the pilosebaceous follicle, is

*Corresponding Author:

\section{Talekar Manisha}

PG Scholar,

Roganidana evam vikriti vijanana department,

National Institute of Ayurveda, Jaipur.

Mob.No- 8824854303

Email-dr.mani21jan@gmail.com considered as an adolescent disorder. Though the disease is not a life threatening one, acne can be upsetting and disfiguring as it presents with papular, pustular and cystic lesions more prominently on the face. When severe it can lead to serious and permanent scaring. It is a well known fact that the disease Yuvanapidaka (acne vulgaris) is not that severe which requires hospitalization, but the necessity for treatment is high as it carries a cosmetic importance.

Now, at this time, when the whole world is showing renewed interest in packaged food or junk food due to shortage of time, busy job schedule, rise in standard of living, convenience \& influence of western countries, people are compelled to change their food habits \& types of food. "Unhealthy diet is one key cause of the growing global burden of disease". Continuous Hetusevana (consumption of causative factors) subsequently enhance the pathogenesis \& results in most of the diseases. Our Ancient Acharyas mainly focused on the Nidana (etiological factors) \& described the detailed description of Nidana for all the diseases. According to A charya Sushruta, avoidance of Nidana or etiological factors is Chikitsa (treatment). (1) Faulty dietary habits are one of the main causes for Yuvanapidaka (Acne vulgaris). Hence to find out cause and effect relationship between faulty dietary habits and Acne vulgaris, this survey study has been selected. It will be contribution to society, making them aware 
about faulty dietary habits and its relation with acne vulgaris.

\section{Aims and Objective:}

To conduct a survey study on pimples producing dietary culprits in Patients of Acne vulgaris.

\section{Material and Methods:}

Total 210 patients having signs and symptoms of Acne vulgaris without any definite age group, of both gender either married or unmarried individuals were included in this study after informed consent. They were selected from OPD and IPD of National Institute of Ayurveda, Jaipur and various camps in Jaipur \& certain junk food outlets. Survey was carried on the basis of specially prepared questionnaires.

\section{Observations:}

Prevalence of Age:

Out of 210 patients, maximum number of patients $(54.28 \%)$ were found in the age group of 26-35 years. The next common age group is $15-25$ years $(27.61 \%)$ followed by $18.09 \%$ patients in age group of $36-45$ years.

Graph 1: Graph Depicting the Age Group of Total Study Patients $(\mathrm{N}=\mathbf{2 1 0})$

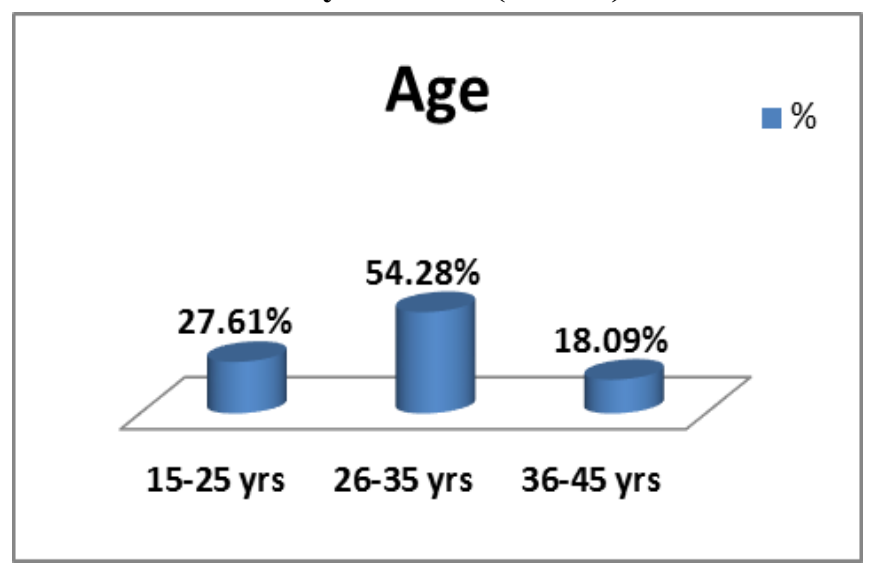

Prevalence of Gender:

Distribution of Gender in 210 patients revealed that $63.33 \%$ of patients were male followed by $36.66 \%$ were female.

Graph 2: Graph Depicting the Gender of Total Study Patients $(\mathbf{N}=\mathbf{2 1 0})$

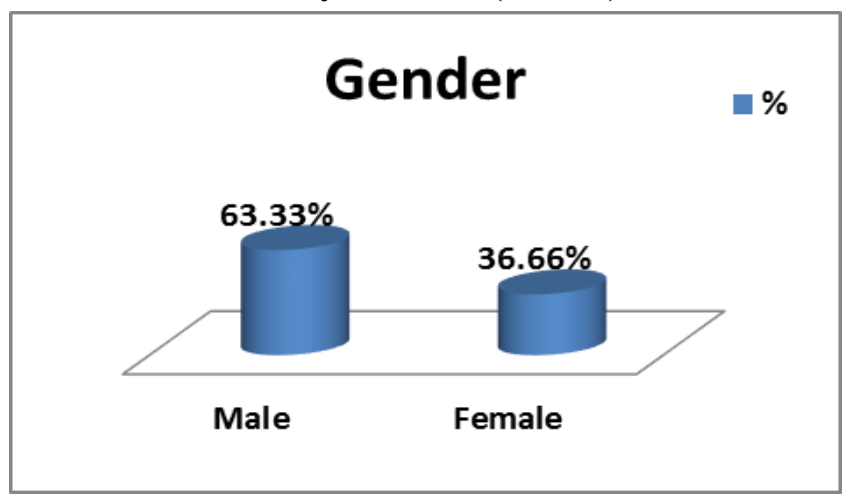

\section{Prevalence of Marital Status:}

Distribution of marital status in 210 patients of Acne vulgaris revealed that maximum $65.71 \%$ patients were unmarried and $34.28 \%$ were married.

Graph 3: Graph Depicting the Marital Status of Total Study Patients $(\mathrm{N}=\mathbf{2 1 0})$

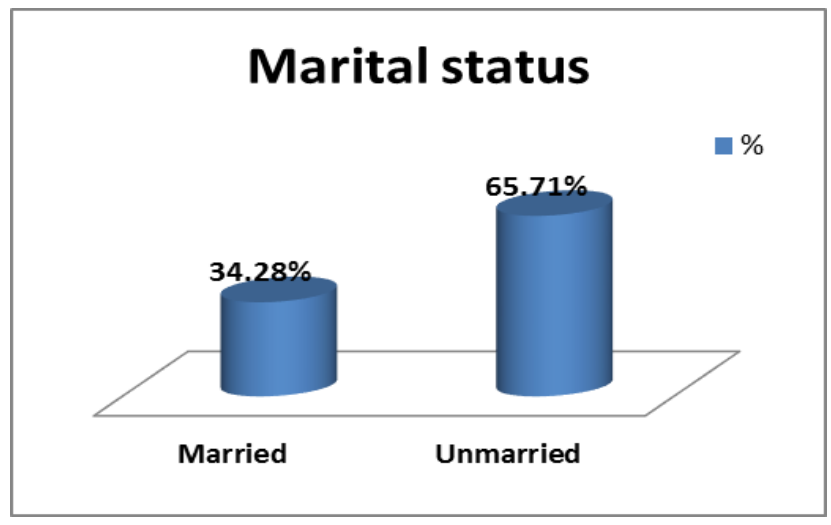

\section{Prevalence of Diet pattern:}

The Diet pattern shows that maximum patients ( $74.28 \%$ ) were vegetarian and $25.71 \%$ of patients were taking mixed diet.

Graph 4: Graph Depicting the Diet Pattern of Total Study Patients $(\mathrm{N}=\mathbf{2 1 0})$

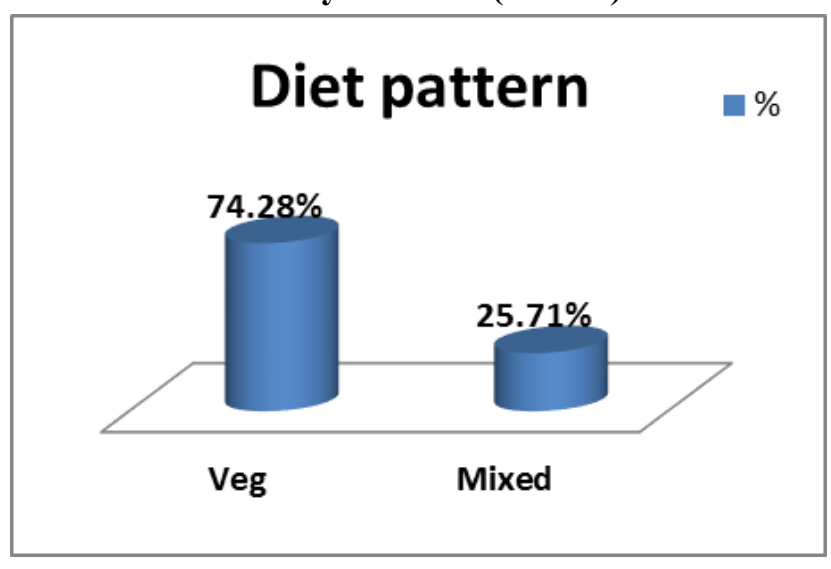

Prevalence of Sharirika Prakriti:

On considering the data of Sharirika Prakriti, maximum i.e. $29.52 \%$ patients had Vata-Kapha Prakriti, 50.95\% had Pitta-Kapha Prakriti and 19.52\% patients had Vata-Pitta Prakriti.

Graph 5: Graph Depicting the Sharirika Prakriti of Total Study Patients $(\mathrm{N}=\mathbf{2 1 0})$

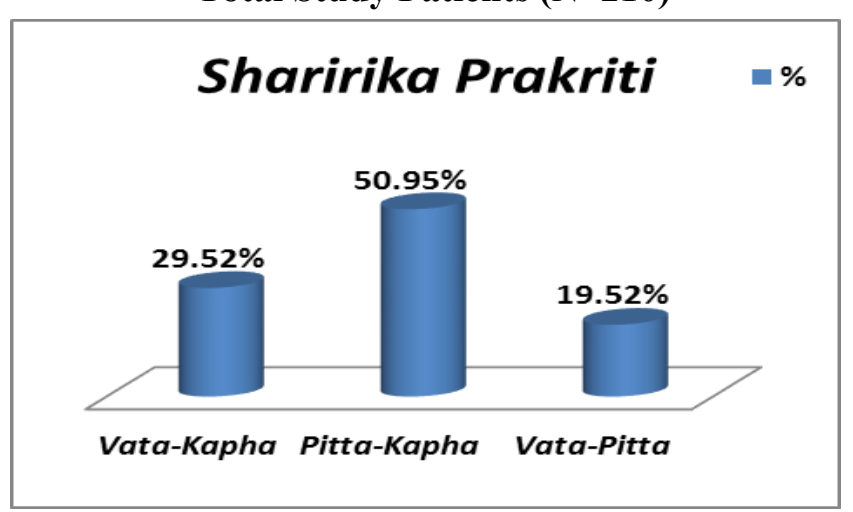


Prevalence of Manasika Prakriti:

On considering the data of Manasika Prakriti, maximum i.e. $53.80 \%$ patients had Rajo-Tama Prakriti, $27.61 \%$ had Satva-Raja Prakriti and $18.57 \%$ patients had Satva-Tama Prakriti.

Graph 6: Graph Depicting the Manasika Prakriti of Total Study Patients $(\mathrm{N}=\mathbf{2 1 0})$

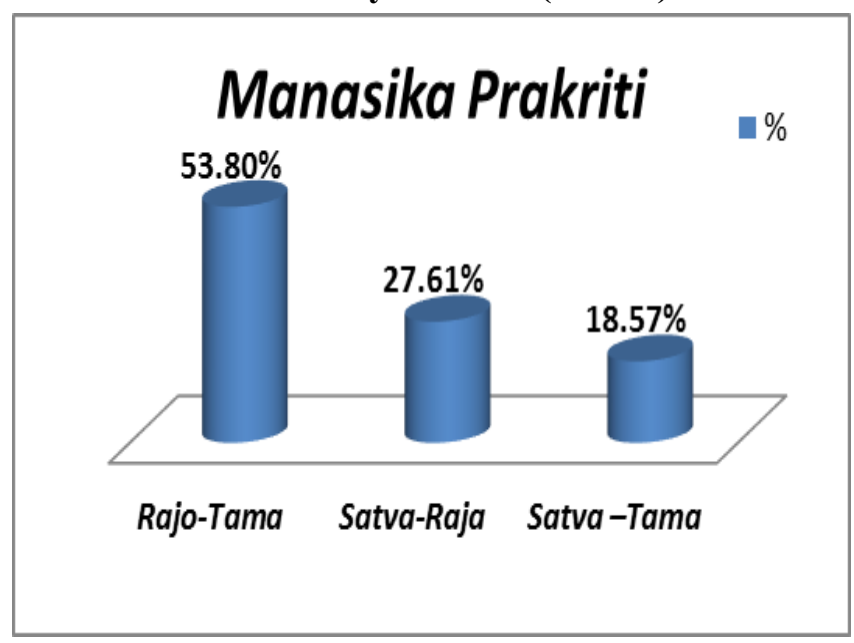

Prevalence of Nidra (sleep):

On considering the history of patients, maximum patients (58.57\%) were adopting Divasvapa (day-sleep) and $22.38 \%$ \& $10.47 \%$ patients having Ati Nidra (excessive sleep) \& Samyaka Nidra (sound sleep) respectively. $8.57 \%$ were having Alpa Nidra. (less sleep).

Graph 7: Graph Depicting the Nidra of Total Study Patients $(\mathrm{N}=\mathbf{2 1 0})$

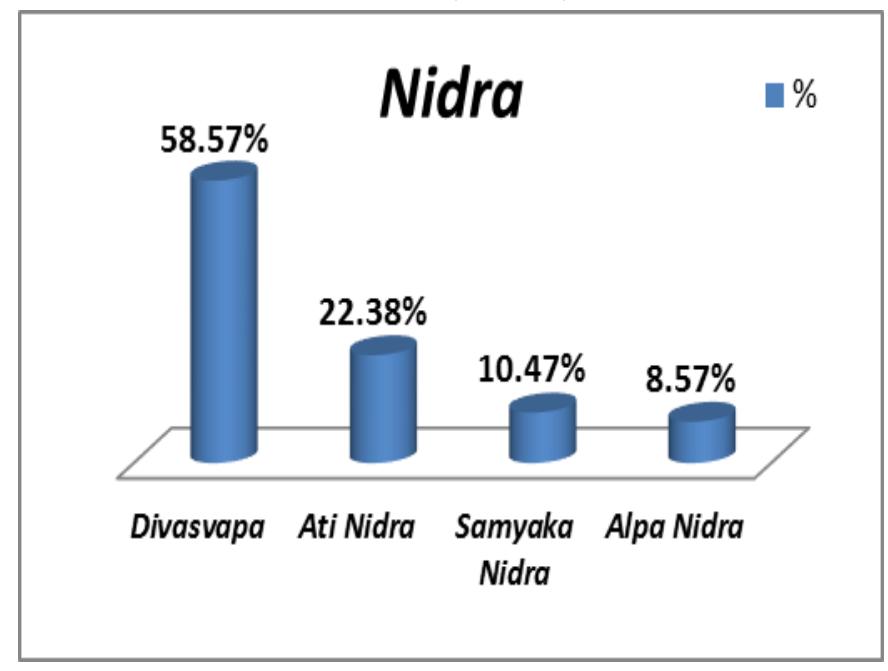

Prevalence of Predominant Rasa Sevana:

Out of 210 patients of Yuvanapidaka, all patients (100\%) were consuming more amount of Madhura Rasa (sweet food items), 92.85\% and 84.28\% patients were taking Lavana Rasa (salty food items) and Amla Rasa (sour food items) respectively. 13.33\% and 10.47\% patients were taking Kashaya Rasa and Katu Rasa respectively. Tikta Rasa (bitter food items) was predominant in $4.76 \%$ patients.
Graph 8: Graph Depicting Predominant Rasa

Sevana of Total Study Patients $(\mathrm{N}=210)$

\section{Predominant Rasa Sevana}

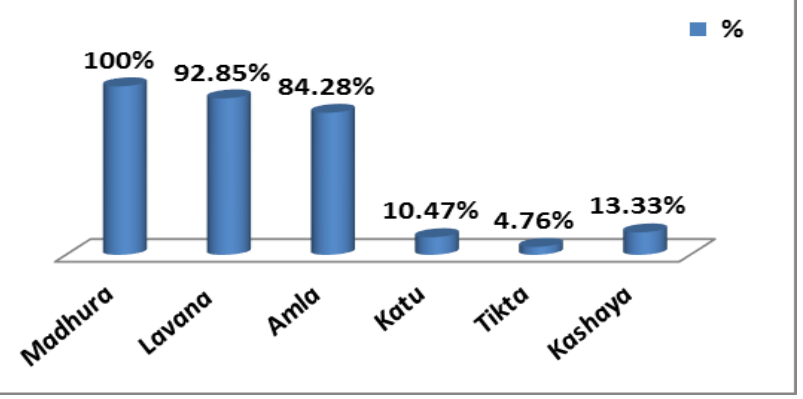

Prevalence of $\boldsymbol{A g n i}$ (digestive fire):

The status of Agni shows that $78.09 \%$ patients were having Mandagni (weak digestive fire), $14.76 \%$ patients were having Vishamagni (erratic digestive fire) and $7.14 \%$ were having Tikshnagni (strong digestive fire).

Graph 9: Graph Depicting the Agni of Total Study Patients $(\mathbf{N}=\mathbf{2 1 0})$

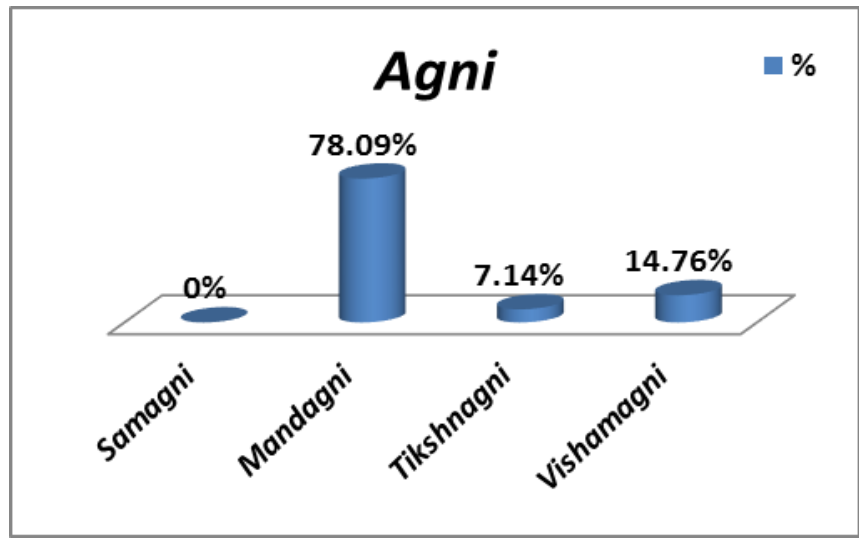

Prevalence of Koshtha:

On analyzing the Koshtha of the patients it was found that $50 \%$ of patients were having Madhyama Koshtha, where $42.38 \%$ patients were with Krura Koshtha and 7.61\% patients having Mrudu Koshtha. (Graph no.10)

Graph 10: Graph Depicting the Koshtha of Total Study Patients $(\mathrm{N}=\mathbf{2 1 0})$

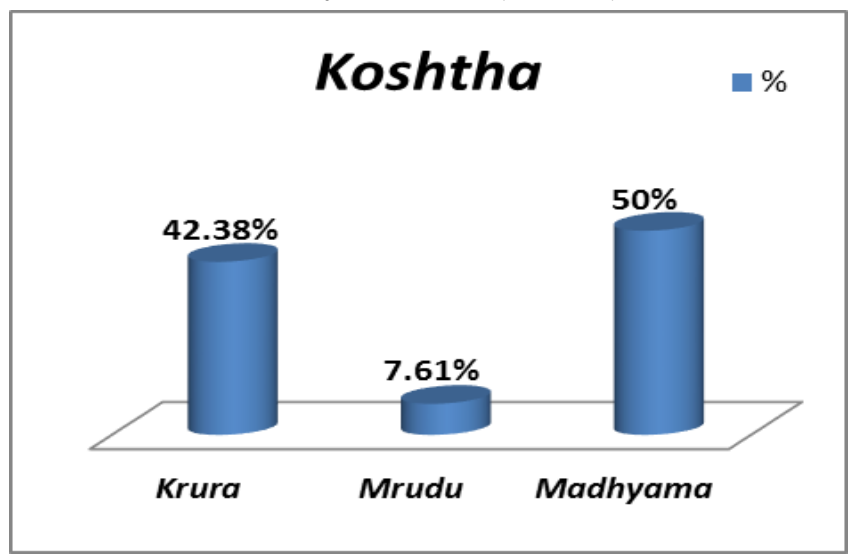


Prevalence of Cardinal Symptoms:

Out of 210 patients of Yuvanapidaka selected for current study, symptoms observed in all the patients were Shalmali Kantakavata Pidaka (pointed lesion) (100\%), Ghanata (immobile) (100\%), Toda (pain) (100\%), Kandu (itching) (69.04\%), Shotha (edema) (92.85\%), Srava (oozing) from the Pidaka (lesion) (50.47\%) and Daha ( burning sensation) (42.38\%). Thus all the cardinal symptoms were observed in all $210(100 \%)$ patients. (Graph no.11)

\section{Graph 11: Graph Depicting the Cardinal Symptoms} of Total Study Patients $(\mathrm{N}=\mathbf{2 1 0})$

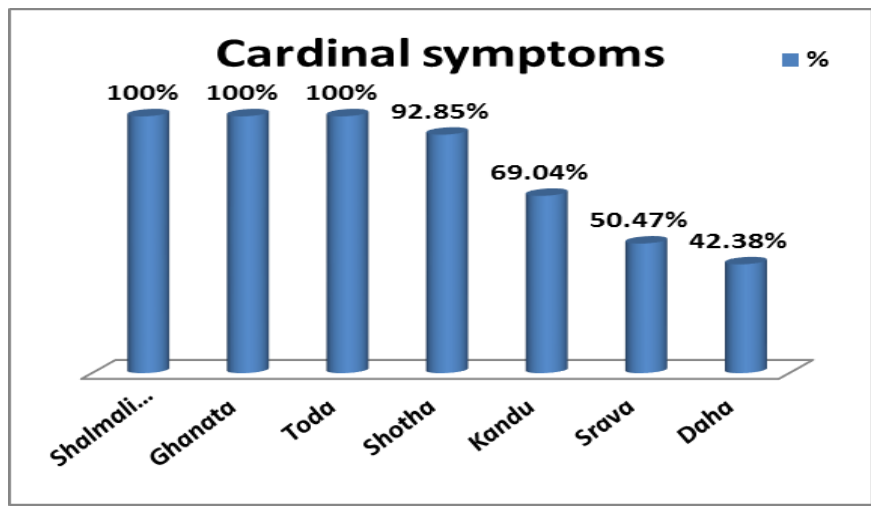

Percentage Prevalence of Patients Faulty Dietary Habits Wise:

Table No. 1: Availability of Nidana (Cause):

\begin{tabular}{|l|l|l|}
\hline Availability of Nidana & $\begin{array}{l}\text { Number of } \\
\text { patients }\end{array}$ & Percentage \\
\hline Fried items & 210 & $100 \%$ \\
\hline $\begin{array}{l}\text { Junk food like samosa } \\
\text { chaat, dabheli, pani puri, } \\
\text { dahi puri, sheva puri, bhel } \\
\text { puri, ragada patis, Oily, } \\
\text { spicy food etc. }\end{array}$ & 210 & $100 \%$ \\
\hline $\begin{array}{l}\text { Yogurt (Curd) } \\
\text { Milk }\end{array}$ & 198 & $94.28 \%$ \\
\hline Milk + sour fruits & 210 & $100 \%$ \\
\hline White rice & 205 & $100 \%$ \\
\hline Milk + Fish & 54 & $97.61 \%$ \\
\hline $\begin{array}{l}\text { Bakery product like cake, } \\
\text { pastries, biscuit, cookies } \\
\text { etc. }\end{array}$ & 210 & $25.71 \%$ \\
\hline $\begin{array}{l}\text { Intake of fruits in excess } \\
\text { quantity viz., Pine-apple, } \\
\text { Watermelon, }\end{array}$ & 197 & $100 \%$ \\
\hline White wheat flour bread \\
\hline $\begin{array}{l}\text { Sweets } \\
\text { drink. }\end{array}$ & 189 & $93.80 \%$ \\
\hline Eating pizza/burger/ & 2102 & $96.19 \%$ \\
\hline
\end{tabular}

On considering the data of Faulty Dietary Habits, it was found that all i.e. $100 \%$ patients were taking Junk food like samosa chaat, dabheli, pani puri, dahi puri, sheva puri, bhel puri, ragada patis, oily, spicy foods etc.; Fried items; milk; milk+sour fruits, bakery product like cake, pastries, biscuit, cookies etc. \& sweets. 97.61\% \& $96.19 \%$ patients were taking white rice and pizza/ burger/snacks along with cold drink respectively. $94.28 \%$ patients were consumed yogurt. Intake of fruits in excess quantity viz., pine-apple and water-melon were consumed by $93.80 \%$ patients. $90 \%$ patients were taking white wheat flour bread. Milk + fish were consumed by $25.71 \%$ patients. (Table no. 1 )

\section{Discussion:}

In survey study, according to Age wise distribution of 210 patients suffering from the Yuvanapidaka (acne), maximum number of patients $(54.28 \%)$ was found in the age group of 26-35 years. The next common age group is $15-25$ years $(27.61 \%)$.

The age between 26-35 yrs is middle age group. This is also the age of predominance of Pitta and Shukra Dhatu, along with consumption of unbalanced food, altered mode of lifestyle, which causes the vitiation of Dosha and Dushya. Modern medical science considered hormonal imbalance, specifically androgen imbalance as one of the important causative factor for the acne, which stimulates the sebaceous glands to produce the excess amount of sebum, by the age of 25 years the maturity level of hormones is attained.

Distribution of Gender in 210 patients revealed that $63.33 \%$ of patients were male followed by $36.66 \%$ were female. According to contemporary science, the males have more problems with the scarring in the long term with acne because males have large more oily prone skin.

Distribution of marital status in 210 patients of Acne vulgaris revealed that maximum $65.71 \%$ patients were unmarried and 34.28\% were married. No direct reference is available about the relation between the marital status and acne symptoms.

The dietary habit of the patients showed that maximum patients $(74.28 \%)$ were vegetarian and $25.71 \%$ of patients were taking mixed diet. Any specific correlation between vegetarian diet and incidence of acne vulgaris may not be established.

On considering the data of Sharirika Prakriti, maximum i.e. 50.95\% patients had Pitta-Kapha Prakriti while $29.52 \%$ patients had Vata-Kapha Prakriti. As mentioned in Samhita, Pitta and Kapha have special role in the manifestation of Yuvanapidaka (acne vulgaris).

On considering the data of Manasika Prakriti, maximum i.e. $53.80 \%$ patients had Rajo-Tama Prakriti. Rajo and Tamoguni persons react more quietly to unfavourable condition. Body and mind always follow one another.

In this study, $58.57 \%$ patients were taking 
Divasvapa and $22.38 \%$ patients having Ati Nidra. As mentioned in Ayurvedic texts, Divasvapa is a direct cause for Rakta Dushti.

In case of dominancy of Rasa, Out of 210 patients of Yuvanapidaka, all patients (100\%) were consuming more amount of Madhura Rasa, 92.85\% and 84.28\% patients were habituated to Lavana Rasa and Amla Rasa respectively. Madhura, A mla and Lavana Rasa in higher incidence may causes vitiation of Kapha. Amla \& Lavana Rasa may provoke Pitta and Rakta Dushti. Kapha and Rakta Dushti may cause Kha-Vaigunya in skin. So these factors influence the production of Yuvanapidaka.

On analysis of Agni, $78.09 \%$ patients were having Mandagni. Due to hypo functioning of $A g n i$, Ama may be produced at any level of digestion \& metabolism. Ama originates from improperly digested toxic particles that clog the channels in our body.

On analyzing the Koshtha of the patients it was found that $50 \%$ of patients were having Madhyama Koshtha, where $42.38 \%$ patients were with Krura Koshtha. Madhyama Koshtha indicates the dominance of Kapha Dosha in Mahasrotasa.

\section{Prevalence of Junk food consumer:}

On considering the data of aggravating diet, prevalence of junk food user like samosa chaat, dabheli, pani puri, dahi puri, sheva puri, bhela puri, ragada patis etc., fried foods \& oily, spicy foods was $100 \%$.

Anything that is processed (frozen, canned, packaged or wrapped) could be considered junk food like: Fried foods, Boxed/Packaged foods, Foods with dyes, Microwavable foods, Restaurant foods, Canned foods, Processed foods. Junk food is a classic example of unbalanced diet usually characterized by high proportion of carbohydrates, refined sugar, salt, fats \& low nutritional value. These essential nutrients like the lipophilic vitamins A, E and D and essential fatty acids (linoleic and $\alpha$-linolenic acid) are involved in numerous important physiological processes, including inflammation. Therefore we could safely assume that absence of these important nutrients from our diet could have important implications for both acne and our overall health. An experimental study which supports a positive link between junk food and acne suggested that the sebum of acne patients is relatively deficient in linoleic acid.(2)

\section{Prevalence of Dairy (Milk) Products:}

On considering the data of Dairy Products consumer, Intake of milk consumption was found in $100 \%$ patients.

According to contemporary classics, Milk is one of the trigger factor for acne because there is abundance of a hormone called IGF-1 (insulin like growth factor-1) in milk, which is growth hormone and good for baby cows, but not for human. IGF-1 is one of several factors that cause inflammation in humans, and which eventually lead to acne (and the ugly redness and swelling that makes acne so annoying). Milk and dairy products cause an insulin spike in humans that cause the liver to produce even more IGF-1, leading to even more acne. Dairy also causes excess sebum (oil) production, leading to more clogged pores, more acne, and a breeding ground for $P$. acnes bacteria, which feed on sebum and spew out inflammatory by-products. The milk and acne effect is well documented in the literature. In the last decade, a number of studies have found a positive association between the consumption of milk and increased occurrence of acne. For example, one such study found that teenage boys who drank milk broke out more often, and more severely, than those who didn't drink milk.(3) At least five other studies have confirmed that, there is an association between drinking milk and acne.(4), (5), (6), (7), (8)

In case of yogurt, it was observed that, $94.28 \%$ patients were taking yogurt. Probiotics are indeed good, but yogurt is not the ideal way to get them because yogurt has some of the IGF-1 removed through the fermentation process, but not entirely, and it still contains natural milk hormones and proteins that tend to cause acne. [Update: extremely acidic, sour yogurt can have significantly reduced amounts of IGF-1, but most store-bought yogurt has a $\mathrm{pH}$ of around 4.8, which isn't low enough to denature the IGF-1 at all.(9)]

\section{Prevalence of High Glycemic Index Diet:}

In survey study, on considering data of faulty dietary intake, prevalence of high glycemic index diet was observed. Intake of Bakery products like cake, pestris, biscuit, cookies etc. \& sweets was consumed by $100 \%$ patents, white rice was consumed by $97.61 \%$ patients, excessive intake of fruits viz. pine-apple, watermelon was observed in $93.80 \%$ patients, $90 \%$ patients were taking white wheat flour bread. These diet having high glycemic index for eg. white flour bread with glycemic index 71, white rice with glycemic index 89, fruits like pine-apple, water-melon having glycemic index 72. Glycemic load of diet is one of the biggest factor affecting hormones.

One prospective cohort study (10) found an association between high-glycemic-index foods and longer acne duration, whereas two randomized controlled trials (11), (12) associated low-glycemicindex diet with reduced acne risk.

\section{Prevalence of Incompatible diet:}

As mentioned in Ayurvedic texts, such type of Ahara or food stuff which is composed of substances having no affinity at all may be defined as Viruddha or Viruddhahara (incompatible diet). In survey study, it was observed that prevalence of incompatible diet like milk + sour fruits was $100 \%$ and intake of pizza/burger/ snacks along with cold drink was found in $96.16 \%$ patients and prevalence of fish + milk was $25.71 \%$. 
Example- eating pizza/burger/snacks along with cold drink. One is -heavy or Santarpanjanya Ahara other is - light or Aptarpanjanya A hara; taking both heavy \& light foods simultaneously cause vitiation of Rakta. In another example- milk + sour fruits, when milk is mixed with sour fruits it gets curdled which is also incompatible. In case of fish + milk, Fish is having property of Guru (heavy), Ushna (hot), Madhura \& Bahudoshakaraka and milk is also having Madhura (sweet) Rasa, Madhura Vipaka (post digestive effect) \& Maha Abhishyandi property (having obstructive property) which causes vitiation of blood and obstruction in body channels.(13) In this way, above examples of incompatible diet responsible for aggravation of acne.

In survey study, these above mentioned faulty diets observed to be the aggravating diet for the lesions. As mentioned in our classical texts, the disease Yuvanapidaka is produced due to vitiation of Kapha, Vata, Rakta and Meda, and above said factors are more Kapha Prakopaka, Medovardhaka, Vata Prakopaka in nature. They ultimately hamper the equilibrium state of Dosha, vitiate the Rakta and lead to development of Yuvanapidaka.

\section{Conclusion:}

From the above observation it is concluded that, dairy products, incompatible diets, high glycemic index diet, junk foods which is responsible for production of acne vulgaris. Majority of people are not aware about these faulty diets. If people avoid these faulty dietary intakes, then production of acne will be controlled up to some extent.

\section{References:}

1. Kaviraj Ambikadutta Shastri, Sushruta, Sushruta Samhita (Part II), Uttara Tantra. $9^{\text {th }}$ ed. Varanasi: Chaukhamba Sanskrit Series, 1995. p. 14.

2. Downing DT, Stewart ME, Wertz PW, Strauss JS. Essential fatty acids and acne. J Am Acad Dermatol. 1986;14:221-225. [PubMed]

3. Milk consumption and Acne in teenage boys. Journal of the American Academy of Dermatology, 2008 May;58(5):787-93. http:// www.ncbi.nlm.nih.gov/pubmed/18194824.
4. Family history, body mass index, selected dietary factors, menstrual history, and risk of moderate to severe acne in adolescents and young adults. Journal of the American Academy of Dermatology, 2012 Dec;67(6):1129-35. http://www.ncbi.nlm.nih.gov/ pubmed/22386050.

5. High glycaemic load diet, milk and ice cream consumption are related to acne vulgaris in malaysian young adults: a case control study. BMC Dermatology, 2012 Aug 16;12:13. http:// www.ncbi.nlm.gov/pubmed/22898209.

6. Role of insulin, insulin - like growth factor-1, hyperglycaemic food and milk consumption in the pathogenesis of acne vulgaris. Experimental Dermatology,18:833-841. http://www.ncbi.nlm.gov/ pubmed/19709092

7. Milk consumption: aggravating factor of acne and promoter of chronic diseases of western societies. J Dtsch Dermatol Ges.2009 Apr;7(4):364-70.http:// www. ncbi.nlm.gov/pubmed/19243483

8. High school dietary dairy intake and teenage acne. Journal of the American academy of Dermatology. 2005 Feb;52(2):207-14. http://www. ncbi.nlm.gov/ pubmed/15692464.

9. The effects of dairy processes and storage on InsulinLike Growth Factor-I(IGF-I) content in Milk and Model IGF-I-Fortified Dairy products.

10.Smith RN, Mann NJ, Braue A, et al. The effect of a high-protein, low glycemic-load diet versus a conventional, high glycemic-load diet on biochemical parameters associated with acne vulgaris: a randomized, investigator-masked, controlled trial. J Am Acad Dermatol. 2007;57:247256. [PubMed]

11.Smith RN, Mann NJ, Braue A, et al. A low-glycemic -load diet improves symptoms in acne vulgaris patients: a randomized controlled trial. Am J Clin Nutr. 2007;86:107-115. [PubMed]

12.Smith RN, Braue A, Varigos GA, et al. The effect of a low glycemic load diet on acne vulgaris and the fatty acid composition of skin surface triglycerides. J Dermatol Sci. 2008;50:41-52. [PubMed]

13.Kashinath Sastri and Dr. Gorakhanath, Agnivesha, Charaka, Charaka Samhita, Sutra Sthana. $1^{\text {st }}$ ed. Varanasi: Chaukhamba Sanskrit Series, 2005.p .518. 